\title{
Pengaruh Model Pembelajaran Kooperatif Tipe Question Student Have (Qsh) Terhadap Hasil Belajar Kognitif Pada Materi Elektrokimia
}

\author{
Ansor Firman Saputra ${ }^{1)}$ ansorfirman@gmail.com. \\ Bimo Budi Santoso ${ }^{2)}$ yanakaresta@gmail.com. \\ Christiana Niken Larasati ${ }^{3)}$ ezrasetiyanto777@gmail.com \\ ${ }^{1}$.Jurusan Pendidikan Kimia UNIPA, MANOKWARI \\ ${ }^{2}$ Jurusan KIMIA UNIPA,MANOKWARI \\ ${ }^{3}$ Jurusan Pendidikan KIMIA UNIPA,MANOKWARI,
}

\begin{abstract}
This study aims to determine the effect of the Cooperative Question Question Have (QSH) type of learning model on cognitive chemistry learning outcomes in Electrochemical material. The research methodology is a type of quasi experiment with a sample of class X students of SMK Negeri 2 Manokwari. The results showed that there was an effect of the QSH type learning model on cognitive chemistry learning outcomes in Electrochemical material at $22.4 \%$
\end{abstract}

Keywords: Cooperative Learning, QSH, Cognitif, Electrochemistry

\begin{abstract}
Abstrak
Penelitian ini bertujuan untuk mengetahui pengaruh model pembelajaran kooperatif tipe Question Student Have (QSH) terhadap hasil belajar kognitif kimia pada materi Elektrokimia. Metodologi penelitian adalah jenis quasi eksperimen dengan sampel peserta didik kelas X SMK Negeri 2 Manokwari. Hasil penelitian menunjukkan ada pengaruh model pembelajaran tipe QSH terhadap hasil belajar kognitif kimia pada materi Elektrokimia sebesar 22,4\%
\end{abstract}

Kata kunci: Pembelajaran Kooperatif, QSH, Kognitif, Elektrokimia

\section{PENDAHULUAN}

Pendidikan merupakan salah satu upaya untuk mencerdaskan kehidupan bangsa yang terdapat dalam pembukaan Undang-undang Dasar 1945. Dengan bertambah baiknya kualitas pendidikan dan sumber daya manusia yang dihasilkan diharapkan dapat membawa perubahan bangsa Indonesia menuju kehidupan berbangsa dan bernegara yang lebih baik.
Dalam konteks pendidikan, hamper semua proses yang dilakukan adalah kegiatan pembelajaran. Kegiatan pembelajaran yang efektif dan efesien akan memberikan hasil belajar yang baik bagi peserta didik. Pembelajaran dapat dikatakan efektif apabila memberikan pengalaman baru kepada siswa, membentuk kompetensi siswa, serta mengantarkan mereka 
ketujuan yang ingin dicapai secara optimal (Rusman, 2013: 144).

Proses pembelajaran pada kurikulum 2013 menggunakan pendekatan scientific. Pendekatan scientific meliputi mengamati, menanya, mencoba, mengolah, menyajikan, menyimpulkan, dan mencipta untuk semua mata pelajaran (Permendikbud, 2013:12). Pendekatan tersebut menciptakan kondisi yang efektif dan efesien sehingga menuntut guru lebih kreatif dalam mencari model pembelajaran agar mendorong peserta didik menjadi lebih berkembang.

Sekolah Menengah Kejuruan (SMK) Negeri 2 Manokwari merupakan salah satu sekolah menengah atas yang sudah menerapkan kurikulum 2013 di tahun ajaran 2015. Tetapi dalam pelaksanaan kurikulum tersebut terdapat beberapa kendala. Berdasarkan hasil observasi di sekolah, tingkat pemahaman peserta didik masih tergolong rendah. Hal ini dikarenakan pembelajaran kurang aktif dan variatif. Proses pembelajaran banyak didominasi oleh guru, peserta didik menjadi kurang aktif sehingga berdampak langsung terhadap hasil belajar yang sebagian besar belum dapat mencapai nilai criteria ketuntasan minimal (KKM) yang ditetapkan yaitu sebesar 65.
Kimia merupakan salah satu mata pelajaran yang dianggap sulit oleh sebagian besar peserta didik sekolah menengah kejuruan (SMK), hal ini disebabkan oleh banyaknya rumus perhitungan yang memerlukan analisis matematis. Berdasarkan halter sebut dalam proses pembelajaran kimia pendidik harus mampu memilih metode maupun model pembelajaran yang tepat pada materi yang diajarkan serta karakteristik peserta didiknya (Aliffah dan Hastuti ) (2013: 35).

Dalam memecahkan permasalahan tersebut guru diharapkan mampu untuk mengembangkan kondisi pembelajaran yang kooperatif, aktif dan efektif serta bervariasi sehingga dapat menumbuhkan minat peserta didik. Salah satu upaya yang dapat dilakukan adalah menerapkan pembelajaran menggunakan model pembelajaran kooperatif tipe Question Student Have (QSH).

QSH dapat diartikan sebagai pertanyaan yang dimiliki peserta didik, pertanyaan ini dapat berupa soal ataupun masalah lain yang belum dipahami. Model ini bias menyemarakkan lingkungan belajar aktif dengan member kesempatan untuk bergerak secara fisik, berbagi pendapat untuk mencapai sesuatu yang mereka banggakan (Silberman 2006: 91). Question Student 
Have (QSH) dapat menarik peserta didik untuk lebih aktif dan terlibat secara mental sehingga berpengaruh pada hasil belajar yang didapat. Hal inilah yang mendorong peneliti untuk menggunakan Question Student Have (QSH) dalam penelitian ini

\section{METODE PENELITIAN}

Metode penelitian ini adalah penelitian kuantitatif dengan Jenis penelitian ini adalah Quasi eksperimen. Sampel pada penelitian ini akan dibagi menjadi 2 yaitu kelas eksperimen dan kelas kontrol. Kelas eksperimen pada kelas X Bangunan B dan kelas Kontrol pada kelas X Bangunan A. Populasi dalam penelitian ini adalah peserta didik kelas X SMK N 2 Manokwari. Teknik pengumpulan data dilakukan dengan :

\section{Observasi}

Observasi yang dilakukan adalah observasi data aktifitas siswa dalam pembelajaran. Observasi ini dilakukan pada kedua kelas sampel yaitu Kelas X Bangunan A dan Kelas X Bangunan B.

\section{Dokumentasi}

Dokumentasi yang dilakukan pada penelitian ini berupa rekaman data baik foto kegiatan siswa maupun hasil kerja siswa.

\section{Wawancara}

Wawancara singkat yang dilaksanakan untuk mengetahui keadaan awal sekolah dan kelas berdasarkan keterangan Guru dan siswa merupakan langkah awal penelitian.

4. Tes

Tes digunakan untuk mengetahui hasil perlakuan terhadap sampel. Jenis tes yang digunakan adalah tespilih anganda sebanyak 25 soal. Tes yang digunakan adalah Pretes untuk mengetahui kemampuan awal dari peserta didik dan post tes untuk mengetahui kemampuan akhir dari peserta didik.

Teknik analisis data adalah ;

1.Uji analisis data Diskritif

2.Uji analisis data Inferensial yaitu: dengan uji normalitas dan uji homogenitas data.

\section{HASIL DAN PEMBAHASAN}

Kemampuan awal peserta didik Kelas Ekperimen dan kelas kontrol. Data hasil pre test peserta didik pada kelas ekperimen didapatkan nilai tertinggi 3 dan nilai terendah 16 dengan nilai terendah 12 dengan rata-rata 28,8 . Hasil analisis data pada uji normalitas menggunakan uji analisis One sample Kalmogrov-Smirna dan uji analisis Shapiro wilk pada kelas ekperimen diperoleh nilai sig $>\alpha$ yaitu $0,075>0,05$ dan 0,05 dan 0,05 , sehingga data berdistribusi normal. Kelas kontrol pada uji normalitas didapatkan nilai $\operatorname{sig}>\alpha$ yaitu $0,200>0,05$ dan $0,725>0,05$ maka 
data pada kelas control terdistribusi normal.

Pada Uji Homogenitas kelas ekperimen dan kelas control digunakan uji analisis Test of homogeneity of Variances didapatkan nilai sig $>\alpha$ yaitu $0,151>0,05$.

Hasil uji pre test kelas ekperimen mempunyai varian yang homogeny kemudian dilanjutkan Uji t, ditunjukkan pada Tabel 1.

Tabel 1. Data Uji Hipotesis (Uji t) pretest

\begin{tabular}{|l|c|c|c|c|c|}
\hline & \multicolumn{2}{|c|}{$\begin{array}{c}\text { Levene's test } \\
\text { forEquality of } \\
\text { Variance }\end{array}$} & \multicolumn{4}{|l|}{} \\
\hline $\begin{array}{l}\text { Equalvari } \\
\text { ances } \\
\text { assumed } \\
\text { equal } \\
\text { Variance } \\
\text { not } \\
\text { assumed }\end{array}$ & 0,484 & 0,491 & 2.382 & 36 & 0,023 \\
\cline { 2 - 6 } & Sig & $\mathrm{T}$ & Df & $\begin{array}{c}\text { Sig. (2- } \\
\text { tailed) }\end{array}$ \\
\hline
\end{tabular}

Berdasarkan tabel 1 diperoleh hasil pada nilai sig $>\alpha$ yaitu $0,382>$ 0,025 yang artinya H0 diterima sehingga dapat dikatakan tidak ada perbedaan kemampuan antara kelas ekperimen dan kelas kontrol. Setelah itu untuk data Post Tes dengan pencaian nilai ketuntasan sebanyak 8 orang pada kelas ekperimen dan 3 orang pada kelas kontrol dan didapatkan hasil dengan nilai rata-rata pada kelas ekperimen yaitu 63,89 dibandingkan dengan kelas control dengan rata-rata 53,47. Senada dengan penelitian dari Robby Abdul
Gani (2016 : 40-43) bahwa ada perbedaan hasil belajar siswa kelas $\mathrm{X}$ Agribisnis pada materi pembiakan tanaman secara generatif antara kelas eksperimen dan kelas kontrol.

Hasil uji post tes kelas eksperimen dikelas kontrol dilakukan analisis uji t, ditunjukkan pada Tabel 2 . Tabel 2. Data Uji Hipotesis(Uji t) posttest

\begin{tabular}{|l|c|c|c|c|c|}
\hline & \multicolumn{2}{|l|}{$\begin{array}{l}\text { Levene's test } \\
\text { forEquality of } \\
\text { Variance }\end{array}$} & \multicolumn{4}{l|}{} \\
\hline $\begin{array}{l}\text { Equalvari } \\
\text { ances } \\
\begin{array}{l}\text { assumed } \\
\text { equal } \\
\text { Variance } \\
\text { not } \\
\text { assumed }\end{array}\end{array}$ & 2,151 & 0,151 & -.885 & 38 & 0,382 \\
\cline { 2 - 6 } & & Sig & $\mathrm{T}$ & Df & $\begin{array}{l}\text { Sig. (2- } \\
\text { tailed) }\end{array}$ \\
\hline
\end{tabular}

Berdasarkan tabel 2 menunjukkan bahwa prasyarat uji hipotesis atau uji $\mathrm{t}$ diperoleh nilai sig $<\alpha 0,023<0,025$. Jadi terdapat perbedaan hasil belajar peserta didik SMK Negeri 2 Manokwari yang mendapat perlakuan dengan model pembelajaran Kooperatif tipe (QSH) dengan kelas yang mendapat model konvensional. Pengaruh model pembelajaran QSH terhadap hasil belajar koqnitif kimia pada materi elektrokimia sebesar 22,4\%. Menurut Nelly dan Siregar. T (2014 15-19) bahwa penggunaan model pembelajaran kooperatif tipe Student Teams Achievement Division (STAD) 
berpengaruh terhadap hasil belajar kimia siswa kelas XI IPA SMA Negeri 1 Manokwari.

\section{SIMPULAN DAN SARAN}

\section{SIMPULAN:}

Terdapat pengaruh model pembelajaran kooperatif tipe Question Student have (QSH) terhadap hasil belajar koqnitif kimia peserta didik kelas X SMK Negeri 2 Manokwari pada materi elektrokimia sebesar 22, $4 \%$.

\section{SARAN :}

$$
\begin{array}{lr} 
& \text { Perlu dilakukan penelitian lebih } \\
\text { lanjut menggunakan } & \text { model } \\
\text { pembelajaran kooperatif } & \text { model } \\
\text { Question Student Have (QSH) } & \text { pada } \\
\text { materi kimia yang lain }
\end{array}
$$

\section{DAFTAR PUSTAKA}

Allifah, N.A dan Hastuti,B.2013. Pengaruh Model Pembelajaran Kooperatif Tipe Teams Games Tour nament (TGT) dan Gaya Belajar Terhadap Prestasi Belajar Peserta Didik Pada Materi Pokok Hidrolisis Garam Kelas XI Semester 2 SMANegeri 4
Surakarta Tahun Ajaran 2012/2013" Jurnal Pendidikan Kimia (ISSN : 2337- 9995, Vol.2,No 4).

Nelly dan Siregar T, Pengaruh penggunaan model pembelajaran kooperatif tipe Student Teams Achievement Division (STAD) kimia terhadap keaktifan dan hasil belajar siswa kelas XI IPA SMA Negeri 1 Manokwari, Jurnal Ilmu Pendidikan Indonesia, 2(3) 10-19

Permendikbud No.81A tahun 2013 tentang Implementasi Kurikulum 2013. Jurnal pendidikan (edisi oktober 2014).

Rusman. Model-model Pembelajaran Mengembangkan Profesionalisme Guru.Jakarta: PT Raja Grafindo Pustaka, 2013.

Robby Abdul Gani, 2016, Hubungan antara model pembelajaran kooperatif melalui metode eksperimen dengan motivasi dan hasil belajar pada materi pembiakan tanaman secara generatif siswa kelas $\mathrm{X}$ agribisnis SMK Negeri 7 jayapura, Jurnal Ilmu Pendidikan Indonesia, 4 (1) 34-43.

Silberman. Strategi Pembelajaran Aktif. Yogyakarta: Pustaka Insan Madani,2006 